\title{
PENGETAHUAN TENTANG PENANGANAN KEGAWAT DARURATAN PADA MAHASISWA
}

\author{
Mona Ariestia \\ Akper Kesdam 1/Bukit Barisan Padang \\ Indonesia \\ e-mail: monaariestia03@gmail.com
}

\begin{abstract}
Abstrak
Kejadian gawat darurat dapat diartikan sebagai keadaan dimana seseorang memerlukan pertolongan segera, karena apabila tidak mendapat pertolongan segera maka dapat mengancam jiwa atau menimbulkan kecacatan permanen. Banyak ditemui mahasiswa yang mengalami suatu kecelakaan baik itu berupa patah tulang, pingsan, terkilir, dan lain-lain diberikan perlakuan yang sama bahkan ada kesalahan dalam memberikan pertolongan ditengah masyarakat. Kondisi ini tentu saja sangat membahayakan apabila berakibat memperparah keadaan penderita. Tujuan penelitian yaitu untuk mengetahui tingkat pengetahuan mahasiswa tentang penanganan kegawat daruratan. Penelitian ini merupakan penelitian kuantitatif. Populasi dalam penelitian ini adalah seluruh mahasiswa TK I Akper Kesdam 1/BB Padang, pengambilan sampel menggunakan total sampling. Hasil penelitian menunjukan dari 46 mahasiswa tingkat pengetahuan tentang penanganan kegawatdaruratan dengan kriteria baik sebanyak 44 orang $(95,6 \%)$ dan 2 orang $(4,4 \%)$ kurang baik.
\end{abstract}

\section{Kata Kunci : Kegawatdaruratan, Bantuan Hidup Dasar, Penanganan Darurat.}

\begin{abstract}
An emergency situation can be interpreted as a situation where someone needs immediate help, because they must not help immediately so they can save lives or attract permanent disability. Many students who suffered damage both broken bones, fainting, sprained, and others were given the same assistance as mistakes in providing help in the community. This condition is of course very dangerous. The purpose of the study was to study the level of student knowledge about emergency management. This research is a quantitative research. The population in this study were all kindergarten students I Akper Kesdam 1 / BB Padang, taking samples using total sampling. The results showed that of 46 students the level of knowledge about emergency management with good criteria as many as 44 people (95.6\%) and 2 people (4.4\%) were not good.
\end{abstract}

\section{Keywords: Emergency, Basic Life Aid, Emergency Management}




\section{PENDAHULUAN}

Keberhasilan pembangun kesehatan di Indonesia tidak lepas dari partisipasi masyarakat. Salah satu peran masyarakat dalam penyelenggaraan upaya kesehatan yaitu melalui berbagai upaya yang dimulai dari diri sendiri, keluarga sampai dengan Upaya Kesehatan yang Bersumber Masyarakat (UKBM) (Depkes, 2010).

Kecelakaan dapat terjadi di rumah, perjalanan, tempat kerja, sekolah, dan tempat lainnya. Sebagai akibat dari kecelakaan korban dapat mengalami cidera ringan atau berat, pingsan, cacat seumur hidup atau bahkan sampai meninggal dunia. Bagi korban yang meninggal dunia tentu tidak memerlukan suatu bentuk pertolongan yang cepat, tetapi bagi korban kecelakaan yang masih hidup memerlukan suatu pertolongan yang cepat dan tepat agar korban dapat terhindar dari bahaya maut. Ilmu pertolongan pertama pada kecelakan sebaiknya di miliki oleh semua orang. Maksud P3K adalah memberikan pertolongan pertama pada kecelakaan ditempat kejadian dengan cepat dan tepat sebelum tenaga medis datang/sebelum korban dibawa ke rumah sakit agar kejadian yg lebih buruk dapat dihindari.

Tujuannya adalah mencegah maut dan mempertahankan hidup, mencegah penurunan kondisi badan/cacat. Kejadian gawat darurat dapat diartikan sebagai keadaan dimana seseorang memerlukan pertolongan segera karena apabila tidak mendapat pertolongan dengan segera maka dapat mengancam jiwanya atau menimbulkan cacat permanen.

Keadaan gawat darurat yang sering terjadi di masyarakat antara lain keadaan seseorang yang mengalami henti napas dan henti jantung, tidak sadarkan diri, kecelakaan, cedera misalnya patah tulang, pendarahan, kasus stroke dan kejang, keracunan dan korban bencana.

Penyebab kejadian gawat darurat yang sering terjadi dalam kehidupan sehari-hari yaitu karena terjadinya kecelakaan lalu lintas, Kasus gawat darurat karena kecelakaan lalu lintas merupakan penyebab kematian utama di daerah perkotaan (Norman, 2006). Keberhasilan pertolongan penderita yang mengalami kondisi gawat darurat tidak hanya ditentukan oleh kualitas dari pelayanan gawat darurat di rumah sakit namun juga keberhasilan pertolongan yang diberikan diluar rumah sakit (pra-hospital), diantaranya yaitu kecepatan menemukan korban, kecepatan minta pertolongan, kualitas pertolongan ditempat kejadian dan penanganan dalam perjalanan ke rumah sakit (Kartasasmita, 2009).

\section{METODE}

Penelitian ini adalah penelitian kuantitatif, sampel diambil secara Total sampling yaitu seluruh populasi dijadikan sampel sebanyak 46 Orang mahasiswa. Data didapatkan dengan cara pengisian kuesioner yang telah disiapkan tekait Pengetahuan mahasiswa. 
HASIL

1. Hasil penelitian Pengetahuan mahasiswa yang dapat dilihat pada tabel 1.

Tabel 1.

Distribusi frekuensi Responden berdasarkan pengetahuan.

\begin{tabular}{|l|c|c|}
\hline Pengetahuan & Frekuensi & $\%$ \\
\hline Baik & 44 & 95,6 \\
\cline { 1 - 2 } Kurang Baik & 2 & 4,4 \\
\cline { 1 - 2 } Jumlah & $\underline{\mathbf{4 6}}$ & $\mathbf{1 0 0}$ \\
\hline
\end{tabular}

Berdasarkan tabel 1 diatas mayoritas responden memiliki pengetahuan baik yaitu sebanyak $(95,6 \%)$.

\section{PEMBAHASAN}

Dari hasil penelitian diatas didapatkan hasil bahwa jumlah mahasiswa yang memiliki pengetahuan baik lebih banyak yaitu sekitar 44 orang $(95,6 \%)$ dibandingkan dengan mahasiswa yang memiliki pengetahuan kurang baik yaitu 2 orang atau (4,4\%).

Dari hasil penelitian tersebut juga di dapatkan bahwa mahasiswa sering menggunakan Fasilitas-fasilitas sebagai sumber informasi yang dapat mempengaruhi pengetahuan mereka. Hal ini didukung oleh penelitian Hermita (2006) dan Irawan (2010) yaitu Seseorang yang mempunyai fasilitas lengkap mempunyai pengetahuan lebih banyak pengetahuan dari pada orang yang mempunyai fasilitas sedikit karena fasilitas merupakan sumber informasi (Notoatmodjo, 2003).

Pada penelitian ini peneliti telah menjajaki apakah responden telah mendapatkan informasi, namun responden beranggapan bahwa mereka dengan mendengar kalimat gawat darurat itu sudah cukup menjadi bagaian dari mendapat informasi, walaupun responden belum pernah mendapatkan informasi penanganan kegawatdaruratan secara lengkap dari sumber informasi formal. Dengan demikian peneliti mengetahui bahwa responden ternyata sudah paham dan mengerti tentang penanganan kegawatdaruratan seperti yang penulis harapkan.

Hasil penelitian ini didukung oleh penelitian yang dilakukan oleh Universitas Sumatera Utara (USU) pada tahun 2009 dengan hasil jumlah sampel sebanyak 207 orang, diperoleh hasil penelitian yang menunjukkan bahwa tingkat pengetahuan responden terhadap kegawatdaruratan mayoritas berada dalam kategori baik yaitu sebanyak 192 orang $(92,8 \%)$, kategori cukup diperoleh sebanyak 14 orang $(6,8 \%)$, dan kategori kurang diperoleh sebanyak 1 orang $(0,5 \%)$.

\section{KESIMPULAN}

Berdasarkan hasil analisa penelitian dan pembahasan dapat diperoleh kesimpulan tentang pengetahuan penanganan kegawatdaruratan pada mahasiswa Akper Kesdam 1/BB Padang yaitu Tingkat pengetahuan mahasiswa yaitu mayoritas mahasiswa memiliki tingkat pengetahuan baik sebanyak 44 orang $(95,6 \%)$. 


\section{SARAN}

Penelitian ini hanya meneliti satu variabel saja dan dengan responden yang relatif sedikit, sehingga hanya menggambarkan hasil penelitian yang sederhana, untuk itu, agar penelitian lanjutan menggunakan jumlah responden yang lebih besar dan dengan cakupan wilayah yang lebih luas, serta dapat menambah variabel penelitian dengan menghubungkan pengetahuan dan sikap, perilaku responden.

\section{DAFTAR PUSTAKA}

Arikunto, Suharsimi. (2006). Prosedur Penelitian Suatu Pendekatan Praktik. Jakarta: Rineka Cipta

Notoatmodjo, S. (2010).Ilmu Perilaku Kesehatan. Jakarta : PT Rineka Cipta.

Nursalam. (2008). Konsep dan penerapan metodologi penelitian keperawatan. Jakarta. Salemba Medika.

Depkes RI. 2007. Riset Kesehatan Dasar Tahun 2007. Jakarta : Depkes RI 
